\title{
Partner care, gender equality, and ageing in Spain and Sweden
}

\author{
By Antonio Abellan ${ }^{1}$, Julio Perez ${ }^{1}$, Rogelio Pujol ${ }^{1}$, \\ Gerdt Sundström², Magnus Jegermalm ${ }^{3}$ \& Bo MalmberG ${ }^{2}$
}

\begin{abstract}
We used national surveys to study how older persons' changing household patterns influence the gender balance of caregiving in two countries with distinct household structures and cultures, Spain and Sweden. In both countries, men and women provide care equally often for their partner in couple-only households. This has become the most common household type among older persons in Spain and prevails altogether in Sweden. This challenges the traditional dominance of young or middle-aged women as primary caregivers in Spain. In Sweden, many caregivers are old themselves. We focus attention to partners as caregivers and the consequences of changing household structures for caregiving, which may be on the way to gender equality in both countries, with implications for families and for the public services.
\end{abstract}

\footnotetext{
${ }^{1}$ Antonio Abellan, Julio Perez \& Rogelio Pujol, Centre for Human and Social Sciences, Spanish National Research Council, Madrid, Spain

${ }^{2}$ Gerdt Sundström \& Bo Malmberg, Institute of Gerontology, School of Health and Welfare, Jönköping University, Jönköping, Sweden

${ }^{3}$ Magnus Jegermalm, School of Education, Health and Social Studies, Dalarna University, Falun, Sweden
} 
International Journal of Ageing and Later Life

Keywords: caregiving, partner care, household pattern, gender equality, Spain, Sweden.

\section{Background}

In many countries in Europe and elsewhere, households of older (and younger) persons are becoming less complex. Increasingly, older people live alone, or - more often - only with their spouse/ partner (Gaymu et al. 2008; Tomassini et al. 2004). The increase in this household type was quite rapid in Sweden, but noticeable also in Spain, thanks to declining mortality, and improved housing and finances of older persons. We analyze how these household patterns influence the gender balance of caregiving for and by older men and women.

Already in the 1980s, British studies reported that many older persons are themselves caregivers, but with small and non-representative samples. With nationally representative data, this insight was captured in the title of one significant study: "The Importance of Third Age Carers" (Askham et al. 1992). In that study, $19 \%$ of persons aged 50-74 were caregivers, compared to $14 \%$ among those over 18 years old. It was noticed that parent caregivers and spouse caregivers were two major groups, providing many more hours of care, and for longer time than other caregivers (caregivers for adult, disabled children are an exception). With rising age of caregivers, parent care declined, while spouse care increased. The study explicitly focused coupleonly households for their analyses of spousal caregiving. Both among married men and women, $3 \%$ of those aged $50-59$, and $4 \%$ of those aged 60-74 were partner caregivers, with about equally many male and female caregivers in absolute terms (personal communication, courtesy Emily Grundy).

Partner caregivers received special attention in some early studies, but mostly with non-representative data (Allen, 1994; Allen et al., 1993). A later study on representative persons aged 70 and above in the USA found that older men and women were about equally likely to care for partners (Feld et al. 2000). Similar results emerge from a later US study (AARP 2014) and Swedish studies (Board of Health and Welfare 2012; Busch Zetterberg 1996; Ulmanen \& Szebehely 2015). Caregivers for partners in these studies often report being alone with big commitments in time and effort. 
A British article has criticized tendentious survey methods and questionable analyses in some early studies of caregiving which (over)emphasized intergenerational care and female caregiving. One study that purportedly demonstrated the overrepresentation of (younger) female caregivers, typically caring for parents/parents-in-law, in fact had nearly as many male caregivers (Fisher 1994). Preconceptions may hinder us from seeing the significance of male caregivers and of older caregivers, including older women as caregivers (Arber \& Gilbert 1989). Other studies have added to this theme, for example Kramer and Thompson's study (2002) and a Swedish study of men who are caregivers for parents/parentsin-law (Wallroth 2016). There are also efforts to raise public awareness about male caregivers (Carers Trust 2014).

With representative census data, an analysis of older persons (65+ years old) and their caregiving in England and Wales found that in couple-only households, $11 \%$ of the men and $13 \%$ of the women appeared to be partner caregivers. Their absolute number was equal, and two thirds of both men and women provided more than 20 hours of care per week. Extensive caregiving increased with age for both men and women in the households where the spouse had a limiting long-term illness and the spouse was likely to be the care provider. These elderly partner caregivers were a disadvantaged group, judging from their financial and educational situation (Young et al. 2006). Using the same source, another study noted that there were altogether more male than female caregivers among older persons (Dahlberg et al. 2007). This was later attributed to gender differences in marital status among older persons (Del Bono et al. 2009) but without specific analysis of couple-only households.

Each new Swedish cohort, including older persons, has more family ties than before (Gaunt 1996; Sundström 2009). This has consequences for family care and for obligations and entitlements over the life-course (Matras 1990). Demographic macro indicators about declining pools of caregivers and similar simple indicators may miss micro changes of family life that are more complex and sometimes contradict macro perspectives (Herlofson \& Hagestad 2011).

Increasing survival leads to longer marriages, in spite of rising divorce rates. Increasing joint survival of spouses means a substantial increase in the chance for having a (married) partner in one's old age, shown for example by 
International Journal of Ageing and Later Life

estimates for Canadian marriages 1921-1981 (Matras 1989). The growth in marriage rates was most visible in the oldest age groups. Our results confirm the trends below.

Caregiving is generally thought to be a female prerogative in any society but could differ between societies of distinct character and culture. We have chosen to compare caregiving in Spain and Sweden, because Spain is assumed to be traditional and familistic, while Sweden is supposedly more modern and individualistic, with more gender equality and extensive welfare programs, which may have diminished male and female informal caregiving. Public services have expanded quite recently in Spain; about $4.5 \%$ of persons of 65 years and above are in nursing homes in both Spain and Sweden, and about 5\% in Spain and 9\% in Sweden use public Home Help services. This suggests that we should expect to find more female caregiving in Spain than in Sweden, regardless of living conditions. We should also expect bigger differences between men and women as caregivers in Spain than in Sweden, regardless of household type. Because of the distinct differences in household patterns between Spain and Sweden, we expect more caregiving inside the more complex Spanish households and more between the comparatively simple households in Sweden. And we finally should expect to find a predominance of female caregivers, in relative and absolute terms, regardless of age, household type, and country.

\section{Methods and Data}

\section{Data}

The best data source for Spain currently available is the 2008 Survey on Disability, Personal Autonomy and Dependency (Encuesta sobre Discapacidad, Autonomía personal y situaciones de Dependencia, henceforth EDAD). This is a very large population survey about health and disabilities, care (received and given), services, and health care $(N=258,187$, for the $65+$ $N=45,553)$, although it may not reflect some recent changes after the LongTerm Care Act, passed in 2006. For Sweden, we primarily used data from Statistics Sweden's Level-of-living survey in 2002-03, which asked questions about caregiving and receipt of care only of the group $55+$ years old 
(Undersökningen av levnadsförhållanden, henceforth ULF; $\mathrm{N}$ for $55+=$ 5,082 , for $65+=2,212$ ).

To ascertain the stability of the findings, we have also analyzed some later population surveys, although regrettably with smaller samples: Centro de Investigaciones Sociológicas (CIS) survey 2009, 2014 ( $N=2,472$ for age 18+, 578 for 65+), for Spain, and for Sweden the 2014 Ersta Sköndal University College survey, ESUC $(N=1,203$ for $16+$, 384 for $65+)$ (von Essen et al. 2015). Both showed patterns of caregiving consistent with our main sources, although rates of caregiving were lower overall in the Spanish EDAD survey (analyses available from the authors). Results in a Swedish government population survey of caregiving in $2012(N=8,202$ for $18+, 2,719$ for $65+$ ) also showed patterns of caregiving consistent with our main sources (Board of Health and Welfare 2012). All three surveys probed caregiving in general, without the main caregiver distinction of the EDAD survey. All evidences refer to persons living in the community and we have attempted to make the analyses between Spain and Sweden as comparable as possible.

\section{Measures}

The term "older persons" refers to persons $65+$, if not otherwise stated, and we refer to partners regardless of marital status. The Swedish survey relies on caregiving in general, and the Spanish survey on main caregivers, hence the scope of caregiving in the two surveys is different. Caregivers for partners in couple-only households, in both countries, often are alone with their caregiving, that is, they are in reality usually main caregivers. In the Spanish EDAD, we have chosen to define disability as limitations in activities of daily living (ADL), and we classify persons as disabled if they report difficulty to perform one or more of six basic or instrumental activities (get out of/into bed, shower/bath, dressing, shopping, cooking, and housework). In the Swedish ULF, we chose to define disability as need of help with one or more of the following activities: cooking, shower/bath, get out of/into bed, dressing, and/or eating. Households are classified into three types: alone, couple-only, and other (Spain only).

In the Spanish EDAD, caregiving is obtained from an additional module of the survey aimed at main caregivers; only persons who claimed to be the main caregiver were selected in the survey. Secondary or sporadic 
International Journal of Ageing and Later Life

caregivers were not considered. The Spanish CIS survey and all the Swedish surveys use a straight-forward question about caregiving, with no distinction about main providers, specifying that the recipient is a person who needs help due to old age, sickness or disability, inside or outside one's household. Our analyses focus on age, gender, household type, disability status, and type of caregiving.

\section{Results}

Among older persons in both Spain and Sweden, living alone or just with one's partner emerge as typical household forms, and in Sweden they prevail altogether, as shown in Table 1.

Increasing proportions of older persons live alone in Spain. Other household types are still common, but declining, while they are quite rare in today's Sweden, where living alone has declined, from about $40 \%$ of the $65+$ in the 1980s, to $32 \%$ in 2015. The reason is simple: older Swedes are increasingly partnered: $52 \%$ of the community living $65+$ were married in 2014 and about $12 \%$ live in a common-law union, most common among 65-79 year old persons. Still another 5-7\% have a romantic partner they are

Table 1. Household structure of older persons ${ }^{1}$ in Spain and Sweden, selected years. Percent

\begin{tabular}{lccc}
\hline & \multicolumn{3}{c}{ Household structure } \\
\cline { 2 - 4 } & Alone & Couple-only & Other \\
\hline Spain & & 33 & 50 \\
1991 & 17 & 33 & 47 \\
2001 & 23 & 42 & 36 \\
2014 & & & \\
Sweden ${ }^{2}$ & 27 & 30 & 33 \\
1954 & 40 & 57 & 3 \\
2002 & 32 & 64 & 3 \\
2015 & & & \\
\hline
\end{tabular}

Note. ${ }^{1}$ Community-residing persons. ${ }^{2} 195467+, 2002$ and $201465+$.

Sources: Spain: INE: Population and Housing Census (1991-2001); Continuous household survey (2014). Sweden: Sundström 2009 and estimates on Statistics Sweden Household Tabulations (2015) (www.scb.se). 
not living with permanently. The historically recent emergence of new types of partnerships and other romantic relations among older persons in Sweden and elsewhere make marital status a poor indicator of lifestyle and household structure (Bildtgård \& Öberg 2015). The latter is visible in a comparison of older Swedes in Tables 1 and 2.

In 2016, $12 \%$ of older Swedish males and $8 \%$ of females were never married, down from much higher rates prevailing into the 1970s. Due to earlier high rates of singlehood of older persons - reflecting demographic patterns among young Swedes well into the 1930 s - about $22 \%$ of older Swedes were childless in the 1970s, compared to about $11 \%$ today (2011). One might expect these changes to result in strengthened family ties and more informal caregiving, inside households for partnered persons, and between households for the rest.

In Spain, 23\% of the $80+$ were married in 1970 and $40 \%$ in 2011. Among people $80+$ in Sweden, 20\% were married in 1950 but 35\% in 2014, and among people $90+, 10 \%$ were married in 1950 but $17 \%$ in 2014 . The relative and absolute increase in married older persons is shown in Table 2.

Table 2. Married older persons by age in Spain and Sweden, selected years. Per cent and population

\begin{tabular}{|c|c|c|c|c|c|c|}
\hline & \multicolumn{2}{|c|}{ Age group } & \multicolumn{2}{|c|}{$\begin{array}{l}\text { Married people } \\
\text { (in thousands) }\end{array}$} & \multicolumn{2}{|c|}{$\begin{array}{l}\text { Total population } \\
\text { (in thousands) }\end{array}$} \\
\hline & $65-79$ & $80+$ & $65-79$ & $80+$ & 65-79 & $80+$ \\
\hline \multicolumn{7}{|c|}{ Spain } \\
\hline 1970 & 54 & 23 & 1491.5 & 120.5 & 2767.0 & 523.7 \\
\hline 1981 & 57 & 25 & 1991.8 & 179.0 & 3511.6 & 725.1 \\
\hline 1991 & 64 & 30 & 2654.8 & 329.5 & 4148.0 & 1080.9 \\
\hline 2001 & 67 & 34 & 3552.8 & 505.6 & 5305.1 & 1491.8 \\
\hline 2011 & 69 & 40 & 3880.3 & 915.7 & 5661.1 & 2272.7 \\
\hline \multicolumn{7}{|c|}{ Sweden } \\
\hline 1950 & 50 & 20 & 308.5 & 22.9 & 614.5 & 106.8 \\
\hline 1975 & 56 & 25 & 573.3 & 56.0 & 1026.2 & 224.6 \\
\hline 2000 & 59 & 31 & 632.6 & 140.6 & 1078.3 & 452.6 \\
\hline 2014 & 58 & 35 & 826.8 & 175.9 & 1413.5 & 499.4 \\
\hline
\end{tabular}

Sources: Spain: INE: Population and Housing Census; 1981-2011, family households. Records. Sweden: our own computations on Statistics Sweden Population. 
International Journal of Ageing and Later Life

When we consider caregiving in couple-only households, the need for help by the partner is of special relevance. Our estimates of need are made as comparable as possible and they suggest that both in Spain and Sweden, the female partner more often needs help with ADL, in relative and absolute terms, up to age 80 . Men have a lower prevalence of ADLneeds also after age 80 , although then being slightly more numerous. It may be mentioned that a vaguer question in the Swedish ULF about longstanding chronic health problems/diseases and need of some kind of assistance showed a similar pattern. These differences are relevant when we consider caregiving between partners.

We illustrate caregiving for Spain in Figure 1, where the big sample allows more detail. In both Spain and Sweden, there is a predominance of female caregivers, but especially so in Spain. A shows main caregivers

Figure 1. Pyramids of main caregivers of disabled persons by household structure and age of caregiver. Spain, 2008 (absolute numbers).

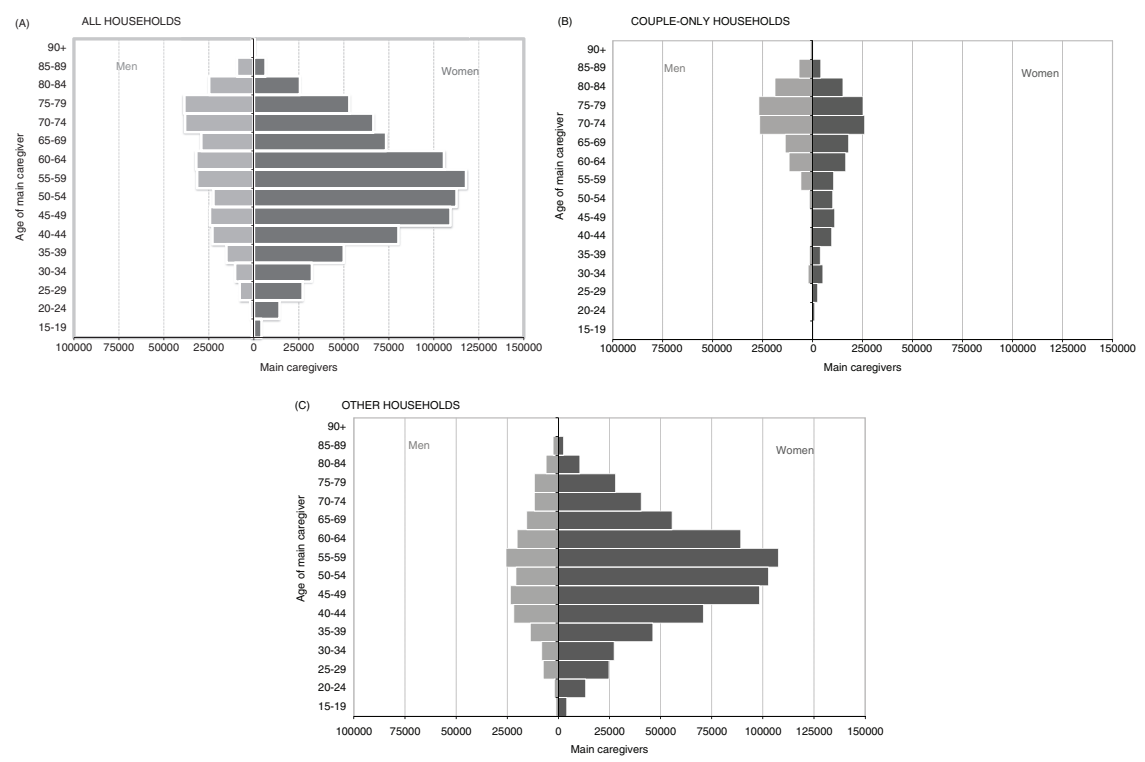


in all Spanish household types, $B$ shows caregivers in couple-only households, and $C$ shows caregivers in other household types (partnered and non-partnered persons in two or three generation households and other constellations).

In Spanish households in general (A), women make up an impressive majority of the main caregivers, most of whom clearly are in their forties and fifties. They usually care for an older person, typically parent(s) or other family member, and thus confirm the general image of the typical caregiver. Male caregivers are fewer and much older, many of whom are in their seventies and eighties, where they seem to be about as many as female caregivers.

The reason for this pattern and the age difference appear in (B), which shows Spanish couple-only households. Here, we find about equal numbers of male and female caregivers in total, but an overrepresentation of male caregivers at higher ages. The dominance of female partner caregivers under age 65 may reflect morbidities and premature mortality that affect men earlier than women during the life course. As more older men are married/ partnered, they are proportionally less likely to be caregivers: $6.2 \%$ of these men are caregivers for their partner, while $7.7 \%$ of these women care for their partner. The difference between these proportions is statistically significant $(z=-4.3 ; p<0.001)$, although the absolute number of male and female caregivers respectively is about equal.

These patterns may be contrasted with other Spanish household types in (C), with overwhelming dominance of female main caregivers. There are many partnered men and women also in these households, where $1.9 \%$ of the men $65+$ are main caregivers for their partner, the corresponding rate is $2.5 \%$ among the women.

For Sweden, smaller samples prevent the detailed breakdowns we have done for Spain. Yet, the picture is more straightforward, as there are, as mentioned, few complex households in today's Sweden. Table 3 uses data on caregiving in the whole Spanish and Swedish population 18+. Parent care increases into middle age and thereafter declines, while partner care increases from about retirement age and dominates caregiving among the oldest persons.

In Spain, there are twice as many female main caregivers as male main caregivers in the age group $55+$. In Sweden, there is only a slight absolute 
International Journal of Ageing and Later Life

Table 3. Caregivers by age in Spain (2008) and Sweden (2012). Percent

\begin{tabular}{llccc}
\hline & & \multicolumn{3}{c}{ Cares for $^{2}$} \\
\cline { 3 - 5 } Age group & Gives care & Partner & Parent(s) & Others \\
\hline Spain & & & & \\
$18-29$ & 2 & 0 & 0 & 0.3 \\
$30-44$ & 4 & 0 & 1 & 1 \\
$45-64$ & 5 & 0 & 3 & 1 \\
$65-79$ & 3 & 3 & 1 & 1 \\
$80+$ & 12 & 3 & 0 & 0 \\
Sweden & 13 & 1 & & \\
$18-29$ & 24 & 1 & 5 & 4 \\
$30-44$ & 19 & 2 & 15 & 7 \\
$45-64$ & 15 & 7 & 5 & 9 \\
$65-79$ & 11 & - & 4 \\
$80+$ & & & & \\
\end{tabular}

Notes. 1. Spain: main carers. 2. Due to roundings, percentages do not always add up correctly. Sources: Spain: INE: Survey on Disability, Personal Autonomy and Dependency, 2008. Sweden: our own elaborations on data in Socialstyrelsen 2012.

overrepresentation of female caregivers among persons $55+$, which is expected as there are more older women than older men. In Table 4, we analyze relative rates of caregiving in detail. We note the small gender difference in partner care, and that in Sweden many more - especially among the women - provide help to family and others outside their household.

Relative rates of caregiving for persons outside one's own household are much higher in Sweden than in Spain, probably because the Spanish survey refers to main caregiver, while the Swedish evidence refers to anyone who provides care, and partly also because of different household structures with proportionally more frail older Swedes living alone and thus inviting more help from outside. Yet, the general pattern and the gradients are similar, with partner care increasingly significant with rising age, and other recipients declining.

Partner care is about equally common among Spanish and Swedish men and women before age 80 as seen in Table 4 . Thereafter, men provide slightly more care, in relative and absolute terms. The risk is higher among 
Table 4. Older caregivers by gender, age, and recipient in Spain (2008) and Sweden (2002-03). Percent and population

\begin{tabular}{|c|c|c|c|c|c|c|c|}
\hline \multirow[b]{2}{*}{ Gender } & \multirow[b]{2}{*}{$\begin{array}{l}\text { Age } \\
\text { group }\end{array}$} & \multicolumn{5}{|c|}{ Gives care to } & \multirow[b]{2}{*}{$\begin{array}{l}\text { Population of } \\
\text { caregivers }\end{array}$} \\
\hline & & Partner & $\begin{array}{l}\text { Other family } \\
\text { in household }\end{array}$ & $\begin{array}{l}\text { Family } \\
\text { outside }\end{array}$ & Other & Total & \\
\hline \multicolumn{8}{|l|}{ Spain } \\
\hline \multirow[t]{3}{*}{ Men } & $55-64$ & 1.7 & 1.0 & & 0.0 & 2.7 & 64,000 \\
\hline & $65-79$ & 3.8 & 0.6 & & 0.0 & 4.4 & 107,000 \\
\hline & $80+$ & 4.7 & 0.4 & & 0.0 & 5.1 & 37,000 \\
\hline \multirow[t]{3}{*}{ Women } & $55-64$ & 1.8 & 6.5 & & 0.2 & 8.5 & 211,000 \\
\hline & $65-79$ & 3.1 & 3.1 & & 0.1 & 6.3 & 186,000 \\
\hline & $80+$ & 1.8 & 0.8 & & 0.0 & 2.6 & 33,000 \\
\hline \multicolumn{8}{|c|}{ Sweden } \\
\hline \multirow{3}{*}{ Men } & $55-64$ & 1.6 & 1.6 & 19.6 & 5.3 & 28.2 & 157,000 \\
\hline & $65-79$ & 3.8 & 0.9 & 7.2 & 10.9 & 22.8 & 111,000 \\
\hline & $80+$ & 5.4 & 0.2 & 2.7 & 7.0 & 15.4 & 25,000 \\
\hline \multirow[t]{3}{*}{ Women } & $55-64$ & 1.7 & 1.8 & 20.9 & 6.7 & 31.1 & 171,000 \\
\hline & $65-79$ & 3.7 & 0.9 & 9.6 & 10.0 & 23.4 & 135,000 \\
\hline & $80+$ & 2.3 & 0.2 & 1.8 & 6.6 & 11.0 & 30,000 \\
\hline
\end{tabular}

Note. 1. Spain: main caregivers. Sweden: all kind of caregivers.

Sources: Spain: INE: Survey on Disability, Personal Autonomy and Dependency, 2008. Sweden: our own elaborations on ULF 2002-03.

partnered persons, increasing with age and relatively similar in Spain and Sweden. For example, among persons living with a partner in the age group $65-79,8 \%$ of Spanish men and 9\% of women are caregivers for a partner. In Sweden, these figures are 6\% and 7\%, respectively (computations available on request from the authors).

In both countries, it is in absolute terms most common to be a caregiver for one's partner in the age group 65-79. The decrease after that age in Spain may be due to persons $80+$ rarely being categorized as main caregivers, for a partner or for someone else, but many may also have lost their partner at that age. In the Swedish sources, all caregivers are considered, but also there we see a decline from age 80 .

Female caregivers care for more types of recipients than male caregivers. In Sweden, the relative risk of caregiving for a partner increases slightly 
International Journal of Ageing and Later Life

with age for women, but more so for men as seen in Table 4 . On the whole, caregiving for a partner is about equally common for women and for men in absolute numbers.

\section{Discussion}

Our results suggest that the differences in household structure, more than potential differences in gender roles and/or a more traditional and familistic Spanish lifestyle, explain most gender differences in caregiving for partners between Spain and Sweden. Men are about as likely as women to care for a partner in couple-only households, an increasingly common phenomenon. Shifts in longevity for men and women suggest that these households will become even more common in the future. More education (illiteracy is still common among older people in Spain), better health, improved finances, and working conditions over the life course point in the same direction.

One initial assumption is confirmed, as there appears to (still) be more female than male caregivers in general, with a very big gender difference in Spain, and a comparatively small one among Swedes, young and old. Yet, in the rapidly expanding couple-only household type, there is no difference between men and women in caregiving for partners. The gender difference in caregiving is thus not universal, and may decline.

Our results support earlier studies, particularly those from Britain, mentioned initially, but we add cultural and demographic aspects by comparing Spain and Sweden. It appears that equality in partner care has some historical stability and consistency across cultural divides. In 1999, $5.9 \%$ of Spanish men and $7.8 \%$ of women were main caregivers for their partner in couple-only households. (Our own computations on INE: EDDES 1999, microdata). Likewise, a Swedish survey in 1994 showed similar caregiving rates (and equal absolute numbers) for male and female partners (Busch Zetterberg 1996). A US survey showed a similar pattern (AARP 2014) and a household survey in Norway in 1988, when more Norwegians lived in complex households and in rural areas than today, found no gender difference in caregiving for a partner in couple-only households (unpublished data, courtesy Dagfinn Ås, NBI). 
The Spanish pyramids of caregivers reflect and confirm the perception that caregivers in general are women, and especially so in Spain. The gradual emergence of couple-only households changes this pattern. Other household types are becoming fewer, as more men and women live with only their partner and then about equally often care for their partner, regardless of cultural differences. This challenges common stereotypes about typical caregivers. It also supports theories about "feminization" of older men, at least in partner care (Pérez Díaz 2003). Caregiving may affect how (older) men negotiate their social roles and their masculinity (Calasanti 2010; Ribeiro et al. 2007; Thomeer et al. 2015; Wallroth 2016). Some critics find it unfair that male caregivers get more attention and question whether their caregiving is really similar to that of women (Milne \& Hatzidimitriadou 2003). Our sources all rely on self-reporting, and it is known that partner caregivers, men and women, generally are reluctant to report themselves as caregivers; they are just "helping" their partner (e.g. Corden \& Hirst 2011).

A limitation of our analyses is that the survey data and other information used are not fully comparable between Spain and Sweden. It is here utilized for lack of better sources, but may still serve the purpose of showing caregiving in various household types. It should be kept in mind that the Spanish EDAD survey focused on main caregivers. This may exclude many older caregivers, male and female, and also caregiving for persons outside one's household, but partner caregivers are often alone with their commitment and are thus mostly main caregivers in both countries. Likewise, the recent Spanish CIS 2014 survey without this restriction supports our findings of equally many male and female caregivers for partners, and so do two recent Swedish surveys (Board of Health and Welfare 2012; von Essen et al. 2015, our own computations on ESUC).

Caregiving is of course prompted by need, and our data suggest that older partnered women more often than men have ADL-needs. A Spanish study of health and functional limitations found similar gender gradients between older (and younger) persons in general in Catalonia over two decades (Solé-Auró \& Alcaniz 2015).

Swedish national surveys, from the early 1990s and onwards, with the latest in 2014 (the aforementioned ESUC), show stability, or even increase of caregiving in the general adult population, including older persons, 
International Journal of Ageing and Later Life

men and women (von Essen et al. 2015 for an overview). In most surveys, $20 \%$ or more of older persons are caregivers. In Spain, a small survey in 2014 showed that $16 \%$ in the general population reported caregiving, $14 \%$ of the men and $18 \%$ of the women. Among older persons, $14 \%$ were caregivers, usually for someone they lived with $(72 \%)$, which appears to often (53\%) be a partner (UDP 2014). In the CIS 2014 survey, $7 \%$ of the $65+$ reported being caregivers, whereof a fifth (19\%) for a partner.

Caregiving may be more common in the general population in Sweden than in Spain, because most older Swedes, including persons in need, live alone or with partner only. They may then receive proportionally more external help, spread on more hands, male and female, resulting in more caregiving between households. In comparison, caregiving inside the household may be more common in Spanish households, as also found in an analysis of the SHARE survey (Board of Health and Welfare 2004).

Another limitation with the type of data sources used by us is that they more or less faithfully show prevalence, but say nothing about how many men and women will sooner or later become caregivers, at all, for parents, for partners or for others. Life-course risks of caregiving may differ for men and women, even if the prevalence is equal. An analysis of the longitudinal US Health and Retirement Study sheds some light on the discrepancy between actual caregiving for a partner and the life-course risk, which appears to be higher for women. The age group $51+$ was followed for twelve years: $29 \%$ were/became caregivers over a two-year span, but $57 \%$ over the twelve year period; for partners, these rates were $6.5 \%$ and $18 \%$, respectively. Married women ran a higher risk to be or become partner caregivers than men: $7.1 \%$ and $6.0 \%$, respectively, over a two year period; over the twelve year period $20.5 \%$ and $16.3 \%$, respectively (Butrica \& Karamcheva 2014).

Wives often outlive husbands (in Sweden 2.5 to 3 times more likely) but there is evidence that men more often die without preceding care needs, or have care needs under a shorter duration, with less severity than women. If this affects reported caregiving is uncertain, but it may have an impact on caregiving volumes (Board of Health and Welfare 2004).

Caregiving may be more a response to the age of the receiver and the associated higher risk of disability, than to traditional gender roles. Swedish partners are often closer in age than older spouses in Spain, 
where a rather large age difference between spouses is (was) more common. This may affect needs for help and caregiving, and there are indications that men receive somewhat more partner care than women when the age-difference is big (EDAD data, not shown).

The vulnerability of couple-only households and partner caregivers is well known to the social services. An indicator of the importance of partner care is the fact that partnered persons - men and women - who need care are less likely to move to nursing homes (or to the household of children), and when they do, they arrive later and for shorter stays, judging from Swedish evidence.

The Spanish Long-Term Care Act (2006) was an important reform, and our results may not reflect some changes which occurred after the law, in particular home-care services and economic compensation to family caregivers, the latter quite common (European Commission 2016). Partnered older Spaniards and Swedes rarely use public services that they are eligible for only when needs are quite extensive. Accordingly, caregivers for partners are little influenced by shifts in public services, as they seldom use them (or only use very little of them) in either country (Abellán \& Esparza 2010; Sundström 2009), nor are they likely to be much influenced by financial incentives.

Older Swedes who live alone are typically older and more frail than partnered persons, a pattern that is less pronounced in Spain, where frail persons may find a refuge in complex households. Social services typically intervene for frail older persons who live alone, and perhaps more so in Sweden than in Spain. When living with only one's partner becomes the norm, and relationships last into advanced age, this may be a questionable policy. In both Spanish and Swedish couple-only households, the partner often is the sole caregiver, although some additional help may be forthcoming from children and others and from daughters more often than sons.

Spouses (and in practice also other partners) are legally expected to support each other in both countries and they often provide extensive care. In one local study in Sweden, partner caregivers - but just a minority among them - were the only applicants for, and users of, support programs for caregivers, mandated by law in 2009. Rather few Swedish caregivers demand support for themselves; rather, most of them want good public 
International Journal of Ageing and Later Life

services for the person they care for (Board of Health and Welfare 2012; Jegermalm et al. 2014).

Our data suggest that household structure, demographic changes, and differences in frailty (needs of care) between men and women, result in older male and female partners increasingly providing about equal amounts of care. Significantly, British evidence suggests small class differences in partner care (Arber \& Ginn 1992). It is difficult to assess changes in culture and behavior, although we have shown emerging similarities in caregiving in culturally different Spain and Sweden.

Caregiving in general and for older persons is more common among women, but the gender difference is much bigger in Spain than in Sweden. Spanish women provide more care inside their household in general, and both Spanish and Swedish women more often than men are caregivers for someone outside of their own household. In Spain, these patterns conceal that partner care is "gender-equal" in couple-only households. This household type is evolving rapidly, with more older caregivers and more male caregivers, a trend that was recently observed also in the USA (AARP 2014, 2015; Span 2015).

The growth of the couple-only household is a striking feature of today's lifestyle of older persons, deriving not only from rising longevity and new living arrangements, but also from changes in education, reproductive behavior, and new generations of older persons. Technological changes, urbanization, better housing, higher pensions, and social services also facilitate living alone or with just a partner in one's old age.

Some studies have indicated a decline of intergenerational care attributed to, mostly, the expansion of public services. Conversely, cutbacks in these services are sometimes blamed for observed increases in support by adults for ageing parents (Sundström et al. 2002; Ulmanen \& Szebehely 2015). Yet, variations in intergenerational exchanges may also be due to more older persons living with only their partner and hence more partner caregivers, a development we witness in Spain and Sweden. When older men and women live with a partner, they see their role as caregivers expand. Historically, this appears as feminization of traditional masculine roles but is caused by the process of ageing: an increase in male survival results in longer marriages/partnerships and changing household structures, with 
more prominent couple-only households. Care provided by older men and women may be on the way to be gender equalized.

\section{Acknowledgements}

The authors would like to thank two anonymous reviewers for their suggestions.

\section{Corresponding Author}

Gerdt Sundström, Institute of Gerontology, School of Health and Welfare, Box 1026, SE 55111 Jönköping, Sweden. Email: gerdt.sundstrom@ju.se

\section{References}

AARP. (2014). Family Caregivers Providing Complex Chronic Care to Their Spouses. Washington, DC: AARP Public Policy Institute.

AARP. (2015). Caregiving in the U.S. Washington, DC: AARP Public Policy Institute and National Alliance for Caregiving. Research Report 2015.

Abellán, A. \& Esparza, C. (2010). Solidaridad familiar y dependencia entre las personas mayores. In M. I. Álvarez Vélez \& F. Montalvo Jääskeläinen (eds.), La familia ante la enfermedad (pp. 203-225). Madrid: Universidad de Comillas.

Allen, S. M. (1994). Gender differences in spousal caregiving and unmet need for care. Journal of Gerontology 49(4): S187-S195.

Allen, S. M., Mor, V., Raveis, V. \& Houts, P. (1993). Measurement of need for assistance with daily activities: Quantifying the influence of gender roles. Journal of Gerontology 48(4): S204-S211.

Arber, S. \& Ginn, J. (1992). Class and caring: A forgotten dimension. Sociology 26(4): 619-634.

Arber, S. \& Gilbert, N. (1989). Men: The forgotten carers. Sociology 23(1): $111-118$.

Askham, J., Grundy, E., Tinker, A. \& Hancock, R. (1992). Caring: The Importance of Third Age Carers. London: Age Concern Institute of Gerontology, King's College. Research Paper Number 6. 
International Journal of Ageing and Later Life

Bildtgård, T. \& Öberg, P. (2015). Förändrade intimitetsformer bland äldre i det senmoderna samhället [Changing forms of intimacy among older persons in late modern society]. Sociologisk forskning 52(1): 5-32.

Board of Health and Welfare. (2004). Framtidens anhörigomsorg. Kommer de anhöriga vilja, kunna, orka ställa upp för de äldre i framtiden? [Family care in the future. Will families be willing and able to take care of elderly family members?]. Stockholm: Socialstyrelsen, Mimeo.

Board of Health and Welfare. (2012). Anhöriga som ger omsorg till närstående. Omfattning och konsekvenser [Informal care: Extent and consequences]. Available on www.socialstyrelsen.se (Accessed: January 1, 2015).

Busch Zetterberg, K. (1996). Det civila samhället $i$ socialstaten: inkomstkällor, privata transfereringar, omsorgsvaird [Civil Society in the Welfare State: Sources of Income, Transfers, Caregiving]. Stockholm: City University Press.

Butrica, B. \& Karamcheva, N. (2014). The Impact of Informal Caregiving on Older Adults' Labor Supply and Economic Resources. Washington, DC: The Urban Institute. Available on http:/ / www.urban.org/research/ publication/impact-informal-caregiving-older-adults-labor-supplyand-economic-resources (Accessed: June 5, 2015).

Calasanti, T. (2010). Gender relations and applied research. The Gerontologist 50(6): $720-734$.

Carers Trust. (2014). Husband, Partner, Dad, Son, Carer? A survey of the experiences and needs of male carers. Available on www.carers.org (Accessed: September 1, 2015).

Corden, A. \& Hirst, M. (2011). Partner care at the end-of-life: Identity, language and characteristics. Ageing and Society 31(02): 217-242.

Dahlberg, L., Demack, S. \& Bambra, C. (2007). Age and gender of informal carers: A population-based study in the UK. Health $\mathcal{E}$ Social Care in the Community 15(5): 439-445.

Del Bono, E., Sala, E. \& Hancock, R. (2009). Older carers in the UK: Are there really gender differences? New analysis of the individual sample of anonymised records from the 2001 UK Census. Health $\mathcal{E}$ Social Care in the Community 17(3): 267-273.

European Commission. (2016). Spain. Health Care and Long-Term Care Systems. The Joint Report on Health Care and Long-Term Care Systems \& Fiscal Sustainability. Institutional Paper 37, Volume 2, Country 
Documents. Available on http://ec.europe.eu/economy finance/ publications/eeip/ip037en.htm (Accessed: December 15, 2015).

Feld, S., Dunkle, R. \& Schroepfer, T. (2000). Characteristics of Spousal Pairs: What Promotes The Choice of Spouse as The Only Caregiver? In Paper presented at the year 2000 Annual Scientific Meeting of the Gerontological Society of America. Mimeo.

Fisher, M. (1994). Man-made care: Community care and older male carers. British Journal of Social Work 24(6): 659-680.

Gaymu, J., Festy, P., Poulain, M. \& Beets, G. (2008). Future Elderly Living Conditions in Europe. Paris: INED.

Gaunt, D. (1996). Familjeliv i Norden [Family Life in the Nordic Countries]. Stockholm: Norstedts.

Herlofson, K. \& Hagestad, G. O. (2011). Challenges in moving from macro to micro. Population and family structures in ageing societies. Demographic Research 25: 337-370.

Instituto Nacional de Estadística. (1999). Encuesta sobre discapacidades, deficiencias y estado de salud, EDDES. Microdatos. [Survey on Disability, Impairment and Health status. Microdata]. Madrid: INE. Available on http://ine.es/dyngs/INEbase/es/operacion.htm?c=Estadistica_C\& cid $=1254736176782 \&$ menu $=$ resultados\&idp $=1254735573175$

Instituto Nacional de Estadística. (2008). Encuesta de discapacidad, autonomía personal y situaciones de dependencia, EDAD. Microdatos. [Survey on Disability, Personal Autonomy and Dependency. Microdata]. Madrid: INE. Available on http://ine.es/dyngs/INEbase/es/operacion.htm? c=Estadistica_C\& cid $=1254736176782 \&$ menu $=$ resultados\&idp $=1254$ 735573175

Jegermalm, M., Malmberg, B. \& Sundström, G. (2014). Anhöriga äldre angår alla! [Older Family Is Everybody's Concern!]. Kalmar: Nationellt kompetenscentrum anhöriga. Kunskapsöversikt 2014:3.

Kramer, B. J. \& Thompson, E. H. (2002). Men as Caregivers: Theory, Research, and Service Implications. New York: Springer.

Matras, J. (1989). Demographic trends, life course, and family cycle - The Canadian example. Canadian Studies in Population 16(1): 1-24.

Matras, J. (1990). Dependency, Obligations, \& Entitlements. A New Sociology of Aging, the Life Course, and the Elderly. Englewood Cliffs, NJ: Prentice-Hall, Inc. 
International Journal of Ageing and Later Life

Milne, A. \& Hatzidimitriadou, E. (2003). “Isn't he wonderful?" Exploring the contribution and conceptualization of older husbands as carers. Ageing International 28(4): 389-407.

Pérez Díaz, J. (2003). Feminización de la vejez y Estado del Bienestar en España [Feminization of old age and the welfare state in Spain]. Revista Espanola de Investigaciones Sociológicas 104: 91-121.

Ribeiro, O., Pauli, C. \& Nogueria, C. (2007). Real men, real husbands: Caregiving and masculinities in later life. Journal of Aging Studies 21(4): 302-313.

Solé-Auró, A. \& Alcañiz, M. (2015). Are we living longer but less healthy? Trends in mortality and morbidity in Catalonia (Spain), 1994-2011. European Journal of Ageing 12(1): 61-70.

Span, P. (2015). More caregivers are no spring chickens themselves. New York Times, The New Old Age, 7 July, 2015, p. D3 of the New York edition. Available on https://www.nytimes.com/2015/ 07/07/health/more-caregivers-are-no-spring-chickens-themselves. html?_r=0 (Accessed: July 8, 2015).

Sundström, G. (2009). Demography of aging in the Nordic countries. In P. Uhlenberg (ed.), International Handbook of Population Aging (pp. 91-111). New York: Springer.

Sundström, G., Johansson, L. \& Hassing, L. (2002). The shifting balance of long-term care in Sweden. The Gerontologist 42(3): 350-355.

Thomeer, M. B., Reczek, C. \& Umberson, D. (2015). Gendered emotion work around physical health problems in mid-and later-life marriages. Journal of Aging Studies 32(1): 12-22.

Tomassini, C., Glaser, K., Wolf, D. A., van Groenou, M. B. \& Grundy, E. (2004). Living arrangements among older people: An overview of trends in Europe and the USA. Population Trends 115: 24-35.

Ulmanen, P. \& Szebehely, M. (2015). From the state to the family or to the market? Consequences of reduced residential care in Sweden. International Journal of Social Welfare 24(1): 81-92.

Unión Democrática de Pensionistas (UDP). (2014) La mitad de los cuidadores informales, sin vacaciones. Boletín UDP XXVIII(256): 12-13. Available on https://www.mayoresudp.org/wp-content/ uploads/2015/02/n256-Como-podemos-construir-comunidades-ami gables.pdf (Accessed: May 10, 2015). 
von Essen, J., Jegermalm, M. \& Svedberg, L. (2015). Folk $i$ rörelse: medborgerligt engagemang 1992-2014 [People on the Move - Civic Involvement 1992-2014]. Stockholm: Ersta Sköndal Högskola. Arbetsrapport 85.

Wallroth, V. (2016). Men do care! A gender-aware and masculinity-informed contribution to caregiving scholarship. Linköping: Linköping Studies in Arts and Science, No. 674, 2016. Diss.

Young, H., Grundy, E. \& Jitlal, M. (2006). Care Providers, Care Receivers. A Longitudinal Perspective. London: London School of Hygiene and Tropical Medicine \& Joseph Rowntree Foundation. Draft version. 